\title{
NUCLEAR PROLIFERATION AND THE CENTRAL BALANCE: STRUCTURAL SCENARIOS
}

\author{
Mihai Vladimir ZODIAN, Ph.D. \\ Researcher, Centre for Defence and Security Strategic Studies, \\ "Carol I" National Defence University, Bucharest, Romania. \\ E-mail: zodian.vladimir@unap.ro
}

\begin{abstract}
This paper synthetizes earlier studies and aims to investigate how the nuclear equilibrium between the United States and the Russian Federation may change, because of the process of proliferation ${ }^{1}$. A theoretical perspective combining power transition and rational deterrence theory is used to draw a few scenarios. The main goal is to develop general traits and tendencies, by varying the variable of power distribution and use them to develop a few scenarios.
\end{abstract}

Keywords: Nuclear weapons, nuclear balance, power transition, deterrence, nuclear strategy, rise of China, prediction.

The theme's importance comes from a few generally accepted ideas on nuclear technology and its consequences. First, the destructive potential and the general belief in the stabilizing effect which they may have upon Great Power relationships are making debates about nuclear weapons still relevant, even after the end of the Cold War and the fall of the Soviet Union. There are also issues the rise or return of China as a great power, including its modernization of the armed forces and the debates on the expansion of the nuclear arsenal. In the academia, the theories about power, armaments and deterrence are controversial and incomplete; thus, any discussion can be useful, and their practical recommendations should be approached with prudence, especially about prediction and concrete policy advice ${ }^{2}$.

Theoretical prediction based on structural analysis is the main method used here. According to the chosen perspective, a few transforming tendencies will be sketched. The epistemological quality of this is speculative, but it may serve some practical needs. For example, how to employ theories to understand better reality and to imagine forms of change, which helps to better cope with it (Chernoff 2012; Zodian, 2015).

This paper is divided in three sections. In the first one, the concepts of equilibrium and proliferation are analyzed, and their characteristics and ambiguities are detailed. Next, a discussion on power transition and rational deterrence theory follows. The last section holds the scenarios, based on the earlier discussion.

\section{What is changing?}

The term equilibrium is notoriously ambiguous (Haas 1953; Wight, 1998) ${ }^{3}$. In nuclear strategy, the most important distinction to be made is the one between parity and vulnerability (Schelling, [1966] 2008, loc 181; Bull, 1998; Buzan 2000; Keohane and Nye 2009). A consequence of the difficulty of defense and of the destructibility of weapons, this reflects the

\footnotetext{
${ }^{1}$ The paper resumes the study Mihai Zodian, Proliferarea nucleară și echilibrul strategic central în secolul XXI, Editura UNAp, 2020.

${ }^{2}$ See also the discussion about balancing from Vasquez and Elman 2012.

${ }^{3}$ For the issue of measuring power, see Miroiu 2005 and Baldwin 2016.
} 
STRATEGIES XXI International Scientific Conference

The Complex and Dynamic Nature of the Security Environment

classical debate between power and security. Power focused explanations, like offensive realism and some versions of transition theory will emphasize primacy, superiority or general equality, while security-focused ones, vulnerability and survivability (Mearsheimer, 2001; Kugler and Zagare, 2008; Waltz 2006; Wohlstetter 2009).

One may start from the basics. In terms of deterrence, the main point is to make a credible threat that presses the opposing side to retreat from an unwanted action, which means that the concept of vulnerability to a response is more important that power in general (Art, 2000). One usually deters by superior force, and this is the message of power transition theory and law enforcement, but the characteristics of nuclear weapons brought a change here, if the consequences are feared and impossible to avoid. Deterrence requires, according to Morrow a military capability, which can exploit this weakness, a clear signaling of intention and that the intention to use the force is believed by the potential challenger, the last two parts enouncing the problem of credibility (Morrow, 2000).

The issue is still controversial. Rational deterrence theory relaxes the assumptions of rationality or perfect information to avoid the paradox that, since the costs are so high either to challenge, or to deter, the whole questions look irrational (Morgan 2003). This is like the paradox of voting, where people vote, even if instrumental comparisons of benefits suggests that they should abstain, but with the difference that deterrence theory is both descriptive and prescriptive, and influenced policy (Downs, 2009; Morrow 2000). Many solutions were proposed, a recent one in the form of risk propensity and Bayesian estimation of credibility (Zagare and Kilgour, 2000), which mixes power with vulnerability; for the purpose of this paper, a classical version of the theory will be used, based on Schelling idea of a threat that leaves something to chance (Schelling, 2000).

There are also many versions of deterrence postures (Narang, 2014). The typical classification, according to the goals pursued, finds minimal deterrence; assured destruction and more ambitious capabilities, ranging from denial to warfighting (Viotti, Kauppi 2013, 307314; Narang, 2014). Even if the force in being is just a part, and the relationship is psychological in great part, different combinations were proposed and linked to distinct types and degrees of stability. While mutual assured destruction (MAD) was often highlighted and recommended, the other options found supporters, and this led to another unsettled series of debates ${ }^{4}$.

Therefore, the concept of nuclear equilibrium does necessarily imply parity or identity of forces and strategies. This view, based on security concerns, and close to the idea of assured destruction, is contrasted with the fact that superpowers often wanted equality or parity in forces or power, not just an admission of unavoidable vulnerabilities (Mearsheimer, 2003). While the drive failed in the sense that redundant capabilities were built, it nevertheless motivated, at least formally the policies pursued by some major actors and may be important in the medium or long term again. Thus, the contemporary nuclear relationship is a combination of ambitious forms of deterrence with formal parity (Narang 2014).

The historical dimension is also significant. The specific postures, capabilities and strategies often changed, especially during the Cold War, which lead to the definition of a central equilibrium between the United States and the Soviet Union, now Russia. While the forces were drastically reduced, the general configuration is still comparable, with the two actors on top, and several others with small arsenals. Since 1945, proliferation was slow compared with the potential, but worries lately were expressed towards the goals of Chinese modernization program, whether it has abandoned minimum deterrence in favor of assured destruction or is it interested in a more ambitious design (DoD 2021).

\footnotetext{
${ }^{4}$ Postures are connected, but not identical with strategies like countervalue, counterforce, first strike etc.; see
} 
This section investigated some of the ambiguities in the ideas of central nuclear equilibrium. The most important is the ambiguity and the risk of confusing the reciprocity of vulnerability with ideas about parity between forces and states. A major disequilibrium may refer to the acquisition of an assured destruction capability by a new nuclear power; the buildup of a massive nuclear arsenal by a previous owner, or the various forms of arms control, disarmament and technological change; I opt for the meaning distinguished by Narang, of big arsenals, available for multiple missions, including assured destruction, to the Great Powers, right now, to the United States and Russia (Narang, 2014). The next segment of this paper holds the theoretical framework.

\section{Why is changing?}

Alterations of the distribution of capabilities are often brought about by arms races and military revolutions (Waltz 2006). Unfortunately, these two phenomena are not very well understood, especially on how to conceptualize them and how to link them with the occurrence and character of war and other possible consequences. For the subject of this paper, is also often confusing those similar issues are approach differently under the label of deterrence and nuclear proliferation, two areas which are close and share similar causal mechanisms. For example, scholars who belief that deterrence policies are stable tend to be more phlegmatic about horizontal proliferation (Waltz 1981).

Understanding arms races is part of this commonality. Buzan distinguished between competitions and dynamics, the first one referring to special contests, involving unusual interactivity and costs, while the second is a contrast, the normal workings of the international system. Allison underlined the value of understanding the internal characteristics and politics of the actors, in his classic (Allison, Zelikow 2010). A.F.K. Organski and Jacek Kugler showed that arms expenditures don't show interactivity, even in the case one may expect that, such as during the Cold War, between the United States and the Soviet Union, proposing one of Allison`s models, the organizational one (Organski, Kugler 1980).

The research expanded further. Other authors used theories about norms culture, symbolic interactions, international diplomacy and sanctions, or economic globalization, but there are still unanswered questions (Solingen 2007; Tannenwald 2009; Narang 2017). One example: under which conditions, a political regime dedicated to growth and welfare who forswears or downplays the role of nuclear weapons may change his strategy? Or, if one considers variables like the international pressures or nuclear postures, as proposed by Narang, the decision to get requires a different explanation.

This line of thinking puts parsimony under question and is difficult to apply. A general approach is needed, but without going too far from the facts, especially since arms dynamics are not autonomous processes, easy to distinguish from political or economic factors (Waltz 2000). Therefore, it will be used a combination between power transition theory and the classical version of rational deterrence theory. The first is a partly structural theory and is useful in building scenarios, because just a few conditions need to be varied; the second avoids the confusion between mutual vulnerability and parity mentioned above.

Power transition theory assumes that certainty leads to peace and ambiguity to war (Vasquez 2009, 57-58). Scholars in this tradition, like Frank Zagare and D. Marc Kilgour approached nuclear weapons like any other type of weaponry, and tried to dismantle rational deterrence theory, arguing that is based on an equality of capabilities. Their proposal, perfect (consistent) deterrence argues that this supposed parity should lead to war, because any of the actors involved may win, an uncertainty related to the result, which can be avoided by a strong nuclear imbalance of capabilities or perceptions (Zagare, Kilgour 2004). But a similar and reciprocal type of vulnerability is not parity and can lead to both clarity and stability, especially if the states can't guarantee that they keep full control during crises or limited wars (Schelling 1967; Walt 1999). 
STRATEGIES XXI International Scientific Conference

The Complex and Dynamic Nature of the Security Environment

Therefore, power transition rational deterrence theory and can be combined, considering their limits. The first one explains war between major powers and rivalry in general based first on the (rapid) catchup of a previously dominating actor by one or more challengers and second, on the rulers' dissatisfaction with the existing international order (Organski, Kugler 1980; Soare 2013). Since parties are becoming comparable in capabilities, any of them has a fair chance to win a war. This uncertainty causes the conflict and is compatible with both explanations in terms of a security dilemma and with James Fearon's model of war, as shown by Woosang Kim and James Morrow`s analysis (Kim, Morrow 1992; Fearon 1995).

The result is underdetermined in two directions. From an operational point of view, the degree of satisfaction is difficult to estimate in a quantitative methodology as the one preferred by power transition`s theorists. Thus, testing involving mostly capability measure show that the power distribution may be a necessary cause, but is not sufficient to cause conflict and war, since in many cases, the parties found a settlement (Vasquez 2009). It's also unclear whether the confrontation should arrive at the beginning of transition, in a preventive war, or close to its end, since the timing depends on the stakes, credibility and negotiations (Kim, Morrow 1992).

These issues of causality suggest that an actor-level interpretation is also needed. Now, rational deterrence theory argues that the power transition should be mostly peaceful because the results are easy to predict and very costly (Waltz 1981; Quackenbush, Zagare 2017). By contrast, the perfect deterrence conceptualization shows that, even with nuclear weapons, there is a considerable risk of war if parties are determined to fight, or they are particularly good at bluffing (Zagare, Kilgour 2004). Thus, the chosen perspective makes a stark difference in threat-assessment.

In this section, some conceptual issues about arms races and nuclear proliferations were reviewed. I argued that a theoretical choice was needed and that the difference is meaningful concerning the conclusions and evaluation. A combination between power transition and rational deterrence explanations was proposed as a solution for the question of prediction. As with any structural interpretation, the precise results are underdetermined, as shown by Kim and Morrow in this case (Kim, Morrow 1992), but the general traits of international system are vastly different, according to the theory employed, and this is the next section`s subject.

\section{How is it changing?}

Any prediction requires to keep some issues constant. In this case, I consider that the international system won 't undergo a fundamental change in principle, type of units or the logic of action. The main idea of this section is to use theoretical prediction, and structural variables to see how the central equilibria may change, a method often employed by neorealists like John Mearsheimer or by power transition theorists like Kugler; the central nuclear equilibria mean here the vast arsenals, capable of multiple missions, retained by the US and Russia after the Cold War (Vasquez 2009; Kugler, Tammen 2009; Mearsheimer; Narang 2014). The specific distribution of power will be varied, in unipolar, bipolar and multipolar, at the systemic level, to generate scenarios, using power transition theory to link structure to the range of anticipable outcomes.

The first scenario is about unipolarity, the system dominated by one power. This means that United States will remain the foremost power, either by good policy, or by a combination of circumstances, including bad management by China`s political leaders (Organski, Kugler 1980; Kugler, Tammen 2009). It's the most peaceful future, if we talk about great power relationship, according to the perspective used in this paper. It's also the most conservative, and easy to question version. 
In this case, how can the central equilibrium change? The baseline expectation is that we shouldn't see much of it, since, by definition, there isn't much use for nuclear weapons, except simple forms of deterrence. The reason is that only one power is capable of global military action, including to protect its allies. Nevertheless, there are a few venues of change: a regionalization of international political system; a reduction of concentration of power in the system, between the pole and competitors; intense nationalism or domestic interests; nevertheless, the best policy in this type of configuration remains to keep the arsenals low or to make a deal with the superpower (Buzan, Waever 2004).

The second scenario is about bipolarity. In this case, there is a distribution of power in which the United States and a second actor, China most likely, are comparable in terms of capabilities. There are several versions, especially the distinction between tight and flexible variants, according to the degree of hostility and pattern of alliances. Seeing from the perspective of power transition theory, it's the most problematic political configuration, in which rivalry may lead to crises and local wars, and the international system is divided between the two poles (Organski, Kugler 1980; Kugler, Tammen, 2009).

It's also an exceedingly popular idea, in the recent years, as argued by many, including Allison with his famous Thucydides trap (Allison, 2017). Especially in tight bipolarity, there are intense structural stimuli for a challenger like China to develop a massive nuclear arsenal, for both prestige and security reasons; the system may be stable or highly conflictual according to a variety of factors, including the beliefs about deterrence (Kaplan 1957) The central nuclear equilibria may become like a balance with three pans, quantitatively and very complex, looking from the vantage of vulnerabilities; for example, the relationship between China and Russia may also influence its configuration, or the rivalry between Beijing and Washington may be less important in the nuclear area (Organski, Kugler 1980; Kugler, Tammen, 2009). In flexible bipolarity, a massive arsenal should be either unlikely or embedded in various arms control regimes; the regional decentralization and deconcentration options are still available.

The third scenario is about multipolarity. In this alternative, there are at least three or four global powers, and with flexible and ambiguous political relationship. It is usually divided in classical multipolarity; Congress type of orders and division in rival alliances polarization, mostly based on modern European history, but other examples can be found (Kaplan 1957). For power transition theory, is a risky and prone to war international distribution of power, but the concrete results may be more temperate, due to different threat perceptions.

In this narrative, the central nuclear equilibria may change, especially if the international system is polarized in two main blocks. The main reason is that alliances are flexible and extended deterrence requires special policies to keep credibility, which means more missions and objectives for a nuclear capability (Organski, Kugler 1980; Kugler, Tammen, 2009). In the classical multipolarity, smaller arsenals and more horizontal proliferation are more probable, since there are more stimuli to pass the buck, as argued by Christensen and Snyder, while a Congress-like order can control the spread of this type of armament. The regionalization possibility collapses in the rest of categories, in this case (Christensen, Snyder 1990).

There are also scenarios in which the distribution of power is less important. For example, a generalized deterrence system based on assured destruction (Kaplan 1957; Waltz 1981); the opposite, a general disarmament; the decline of any of the two major nuclear powers or technological change. They aren $t$ the focus in this paper but is important to be aware of the many other alternatives. Their probabilities seem to be low.

\section{Conclusions}

There are still ambiguities in the use of the balance or equilibrium metaphors in International Relations. For the topic approached here it is important to notice and underline the oscillation between vulnerability and equality when discussion the situation of the United 
STRATEGIES XXI International Scientific Conference

The Complex and Dynamic Nature of the Security Environment

States and Russia. The meaning employed here includes both deterrence based on assured destruction and significant dimensions. This vagueness will probably remain in the literature.

The theoretical perspective combined power transition and rational deterrence theory. An idea rejected by some power transition theorists, it offers enough simplicity to deploy structural analysis and narrate a few major scenarios. Power transition argues that imbalance of capabilities leads peace, offering a way to link structure to results. Rational deterrence theory simplifies the choice of variables.

The main scenarios followed the three classical international systems. The bipolar version is the most unstable, according to the theory, and a power like China may pursue the developing of a vast nuclear arsenal. The multipolar system comes next, in which more countries may be involved in complex rivalries. The unipolar seems to be the more stable, taking great powers relationships into account; there are different variables for each, according to institutionalization and degree of hostility.

\section{BIBLIOGRAPHY:}

ART, Robert. 1980. "To What Ends Military Power". International Security. 4(4): 3-35.

BALDWIN, David A. 2016. Power and International Relations. A Conceptual Approach, Princeton: Princeton University Press.

BULL, Hedley. 1998 [1977]. Societatea anarhică. Studiu asupra ordinii în politica mondială, Chișinău: Editura Știința/CEU Press.

BUZAN, Barry, WAEVER, Ole. 2004. Regions and Powers. The Structure of International Security. Cambridge: Cambridge University Press.

BUZAN, Barry. 2000 [1991]. Popoarele, statele și teama. Chișinău: Editura Cartier.

CHERNOFF, Fred. 2012. The Power of International Theory. Reforging the Ling to Foreign Policy-Making Through Scientific Enquiry. London, New York: Routledge.

CHRISTENSEN, Thomas J., and SNYDER Jack. 1990. "Chain Gangs and Passed Bucks: Predicting Alliance Patterns in Multipolarity". International Organization 44 (2): 137168. doi:10.1017/s0020818300035232.

DoD. 2021. Military and Security Developments Involving the People`s Republic of China 2021. Annual Report to the Congress. Office of the Secretary of Defense.

DOWNS, Anthony. 2009 [1954]. O teorie economică a democrației. Iași: Institutul European.

GRAHAM Allison, ZELIKOW T., Philip D. 2010 [1971, 1999]. Esența deciziei. O explicație a crizei rachetelor din Cuba. Iași: Polirom.

GRAHAM Allison. 2017. Destined for War: can America and China escape Thucydides's Trap? Boston: Houghton Mifflin Harcourt.

HAAS, Ernst B. 1953. "The Balance of Power: Prescription, Concept, or Propaganda", World Politics. 5(4): 442-477.

KAPLAN, Morton A. 1957. System and process in International Policies. Wiley: New York.

KEOHANE, Robert O., NYE, Joseph S. Jr. 2009 [1977]. Putere și interdependență. Iași: Polirom.

KIM, Woosang, MORROW, James D. 1992. "When Do Power Shifts Lead to War?". American Journal of Political Science 36 (4): 896.

KUGLER, Jacek, TAMMEN, Ronald L. 2009. in William R. Thompson (ed.), Systemic Transitions. Past, Present, And Future. New York: Palgrave MacMillan.

KUGLER, Jacek, ZAGARE, Frank C. 1990. "The long-term stability of deterrence", International Interactions, 15(3-4), pp. 255-278, DOI: 10.1080/03050629008434733 
MEARSHEIMER, John J. 1990. "Back to the Future: Instability in Europe after the Cold War". International Security. 15(1): 5-56.

MEARSHEIMER, John J. 2003 [2001]. Tragedia politicii de fortă. Bucuresti: Antet XX Press. MIROIU, Andrei. 2005. Balanță și hegemonie. București: Editura Tritonic.

MORGAN, Patrick M. 2003. Deterrence Now. Cambridge, New York: Cambridge University Press.

MORROW, James D. 2000. "The Ongoing Game-Theoretic Revolution". In Midlarsky, Manus I. (ed.). Handbook Of War Studies II. Ann Arbor: University of Michigan Press.

NARANG, Vipin. 2014. Nuclear Strategy in the Modern Era: Regional Powers and International Conflict. Princeton: Princeton University Press.

NARANG, Vipin. 2017. "Strategies of Nuclear Proliferation: How States Pursue the Bomb". International Security 41 (3): 110-150. doi:10.1162/isec_a_00268

ORGANSKI, A. F. K, KUGLER, Jacek. 1980. The War Ledger. Chicago: The University of Chicago Press.

QUACKENBUSH, Stephen L., ZAGARE, Frank C. 2017. "Modern Deterrence Theory: Research Trends, Policy Debates, and Methodological Controversies". Oxford Handbooks Online, May 2016, DOI: 10.1093/oxfordhb/9780199935307.013.39

SCHELLING, Thomas C. 1967. Arms and Influence, Yale University Press, Kindle edition, 1967.

SOARE, Simona. 2013. "Tranziția de putere". In Biró, Daniel. 2013. Relații internaționale contemporane. Iași: Editura Polirom.

SOLINGEN, Etel. 2007. Nuclear Logics: Contrasting Paths in East Asia and Middle East. Princeton: Princeton University Press.

TANNENWALD, Nina. 2009. The Nuclear Taboo: The United States and the Non-Use of Nuclear Weapons Since 1945. Cambridge: Cambridge University Press.

VASQUEZ, John A., ELMAN, Colin (eds.). 2012 [2003]. Realismul și balanța de putere, Iași: Polirom.

VIOTTI, Paul R., KAUPPI, Mark V. 2013. International Relations and World Politics. Boston: Pearson.

WALT, Stephen M. 1999. "Rigor Or Rigor Mortis? Rational Choice and Security Studies". International Security 23 (4): 5-48. doi:10.1162/isec.23.4.5

WALTZ, Kenneth N. 1981. "The Spread of Nuclear Weapons: More May Be Better: Introduction". The Adelphi Papers 21 (171): 1-1. DOI: doi:10.1080/05679328108457394

WALTZ, Kenneth N. 2000 [1954]. Omul, statul și războiul. Iași: Institutul European.

WALTZ, Kenneth N. 2006 [1979]. Teoria politicii internaționale. Iași: Polirom.

WIGHT, Martin. 1998. Politica de putere, Chișinău: Arc.

WOHLSTETTER, Albert. "Theory and Opposed-Systems Design", In Zarate, Robert. Sokolski, Henry (eds.), 2009. Nuclear Heuristics: Albert and Roberta Wohlstetter, Carlisle: The Strategic Studies Institute.

WOHLSTETTER, Albert. 1959. "The Delicate Balance of Terror". In Zarate, Robert. Sokolski, Henry (eds.), 2009. Nuclear Heuristics: Albert and Roberta Wohlstetter, Carlisle: The Strategic Studies Institute.

ZAGARE, Frank C. KILGOUR, D. Marc. 2004. Perfect deterrence. Cambridge: Cambridge University Press.

ZODIAN, Mihai. 2015. Perspective epistemologice și predicții în relațiile internaționale. București: Editura Universității Naționale de Apărare „Carol I”.

ZODIAN, Mihai. 2020. Proliferarea nucleară şi echilibrul strategic central în secolul XXI, București: Editura Universității Naționale de Apărare „Carol I”. 